\title{
Duygu Yüklü Kelimelerin İșlenmesinde Konfigürasyon Temelli Temsiller
}

\section{Emotional Word Processing Within Configural Representations}

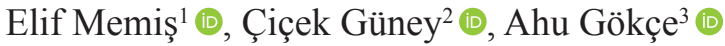

Yazar notu: Elif Memiş ve Çiçek Güney bu makaleye aynı oranda katkıda bulunmuşlardır ve birinci yazarlığı paylaşmaktadırlar.

*Bu çalışma 2018 yılında Psychonomic Society International Meeting kongresinde bildiri olarak sunulmuştur.

${ }^{1} Y u ̈ k s e k$ Lisans Öğrencisi, Yeditepe Üniversitesi Bilişsel Bilimler Yüksek Lisans Programı, İstanbul, Türkiye ${ }^{2}$ Yüksek Lisans Öğrencisi, İstanbul Üniversitesi Deneysel Psikoloji Yüksek Lisans Programı, İstanbul, Türkiye

${ }^{3}$ Dr. Öğr. Üyesi, Kadir Has Üniversitesi, İstanbul, Türkiye

ORCID: E.M. 0000-0003-2388-4171;

Ç.G. 0000-0002-5251-3292;

A.G. $0000-0002-5032-7007$

Sorumlu yazar/Corresponding author: Ahu Gökçe,

Kadir Has Üniversitesi, İstanbul, Türkiye

E-posta/E-mail: ahu.gokce@khas.edu.tr

Başvuru/Submitted: 14.02.2019

Revizyon Talebi/Revision Requested: 30.04.2019

Son Revizyon/Last Revision Received:

22.10.2019

Kabul/Accepted: 24.10.2019

Online Yayın/Published Online: 27.03.2020

Atıf/Citation: Memis, E., Guney, C., Gokce, A Duygu yüklü kelimelerin işlenmesinde konfigürasyon temelli temsiller. Psikoloji Çalışmaları - Studies in Psychology, 40(1): 79-104.

https://doi.org/10.26650/SP2019-0014

\section{öz}

Duyguların bilişsel süreçlere etkisi son yıllarda sıklıkla çalışılan bir konu olmuştur. $\mathrm{Bu}$ çalışmada duyguların görsel-mekansal dikkat süreci ile ilişkisinin incelenmesi amaçlanmıştır. Bireylerin görsel-mekansal dikkat süreçleri, konfigürasyon oluşturan kelimelerin lokalizasyon görevi sırasında işlenmesi yoluyla incelenmiştir. Lokalizasyon görevinde katılımcılardan gördükleri fiksasyon işaretinin ('+') rengi ile aynı renkte yazılı olan kelimenin konfigürasyondaki yerini klavyede önceden belirlenen tuşa basarak belirtmeleri istenmiştir. Her denemede, farklı renklerde dört kelime, bir kare konfigürasyonu oluşturacak şekilde konumlandırılmıştır. Farklı deney koşullarında kare konfigürasyonu oluşturan kelimeler duygusal değerlikte (nötr, pozitif ve negatif kelimeler) farklılık göstermiştir. Denemeler arası geçişlerde (deneme $1 \rightarrow$ deneme 2) hedef uyaranın konfigürasyondaki yeri (örn., sağ üst köşe), konfigürasyonun büyüklüğü (büyük ya da küçük kare) ve kelime türü (duygu yüklü, nötr kelime) değişiklik göstermiştir. $\mathrm{Bu}$ çalışmanın temel amacı, duygu yüklü ve nötr kelimelerin işlenmesi sürecinde etkili olan değişkenler arasındaki etkileşimi incelemektir. Bu değişkenler, dikkatin yönlendirildiği alanın boyutu ve denemeler arasında tekrarlanan ya da değişen hedef uyaran konum tespitidir. Kare konfigürasyonun denemeler arasında büyük ya da küçük olması dikkatin yönlendirildiği alanın boyutunu belirlemektedir. Sonuçlar kullanılan kelime türünün ve konfigürasyon boyutunun lokalizasyon görevi performansında farklılığa yol açtığını göstermektedir. Nötr ve negatif kelimeler kullanıldığında hedef uyaran lokasyonun denemeler arasında tekrarlanmasının tepki süresinin uzamasına sebep olduğu bulunmuştur. Hedef uyaranın lokasyonu farklı olduğunda ise katılımcıların tepki süresinin kısaldığı, yani kelimenin işlenmesinin daha kolay olduğu gösterilmiştir. Ayrıca, yalnızca duygu yüklü kelimeler kullanıldığında büyük konfigürasyonların küçük konfigürasyonlara göre daha iyi bir performansa yol açtığı gözlemlenmiştir. Çalışma kapsamında elde edilen bulgular, kelime uyaranlarının kullanımı ile konfigürasyonların otomatik olarak oluştuğunu ve duygu yüklü ve nötr kelimelerin farklı şekilde işlenmesinde etkisi olduğunu göstermektedir.

Anahtar Kelimeler: Duygusal kelime işlenmesi, konfigürel temsiller, global/ yerel işleme süreçleri, görsel tarama, mekansal dikkat 


\section{ABSTRACT}

The impact of emotions on cognitive processes has been studied intensively in the last years. The aim of the present study is to investigate the relationship between visuospatial attention processes and emotions. Visuospatial attention processes were investigated by using a localization task which required processing of the words that formed the configuration. In the localization task, participants were asked to indicate the position of the target word which matched the color of the fixation cross ("+") by pressing the relevant keyboard button. In each trial, four words in different colors were positioned to form a square configuration. In different experimental conditions, words that formed the configuration varied in their valence (neutral, positive and negative words). The intertrial transitions (trial $1 \rightarrow$ trial 2) consisted of changes in the target's location within the configuration (e.g. top right corner), size of configuration (big/small square) and type of word (emotional/neutral). The main goal of the present study is to investigate the interaction between the processing of emotional and neutral words and certain variables. The variables were the size of the attended area and localizing the target word that was repeated or changed across trials. By changing the size of the configuration (small / big sized square) across trials, the size of the attended area was determined. The results revealed that changes in word valence and size of the configuration led to differences in the localization task performance. It was found that neutral and negative words led to target location repetition cost. Different location targets were processed faster suggesting that word processing was easier. Additionally, bigger, compared to smaller configurations, led to better performance only when emotional words were used. Overall findings of the present study suggest that configural representations are formed automatically by using the word stimuli, and they influence the processing of emotional and neutral words differently.

Keywords: Emotional word processing, configural representations, global/local processing, visual search, spatial attention

\section{EXTENDED ABSTRACT}

The effect of emotion on various cognitive processes such as memory, attention and perception has been reported previously (Brosch, Scherer, Grandjean, \& Sander, 2013). The findings show both facilitatory and inhibitory effects of emotions on cognitive performance. The aim of the present study is to investigate the processing of positive, negative and neutral emotional stimuli presented within configurations. More specifically, the processing and representation of emotional words within the formed spatial configurations will be investigated. It has been shown that the configural representations are formed automatically and aid the visual detection performance (Boduroglu \& Shah, 2009). In the present study, the spatial configuration context, i.e. the small or big square, was formed by placing the words in the form of a square arrangement. In three conditions, different word types (neutral, positive and negative) were used in order to investigate the differences in the processing of emotional and neutral words. Another scope of the current study was to investigate the differences in global and local processes, and their modulation by emotions as previous studies showed that global and local processes are influenced by emotions (Clore, Gasper \& Garvin, 2001; Gable \& Harmon-Jones, 2010). Differences in the task performance were expected when small $\rightarrow$ small and big $\rightarrow$ big transitions were used reflecting the global and local processes. In addition, differences in emotional (positive/negative) versus neutral 
word processing were expected in different configural transitions. Positive words in the big configurations (global level) and negative words in the small configurations (local level) were expected to facilitate the task performance and fasten the reaction time (Gasper \& Clore, 2002). Lastly, repetition of the target location was expected to result in speeded and more accurate target localization performance.

\section{Method}

The global and local processes were investigated by varying the size of the square configuration across trials (big $\rightarrow$ big, big $\rightarrow$ small, small $\rightarrow$ small, small $\rightarrow$ big transitions from previous to the current trial, i.e. trial $n-1 \rightarrow$ trial $n$ ). In such design, the configuration itself is assumed to be processed at the global level while the individual stimuli (words) that form the configuration are assumed to be processed at the local level. Regarding the inter-trial transitions, the target's location within the configuration was either at the same or different location in equal proportion (e.g., top left corner across subsequent trials). The size of the configuration and location of target changed randomly, and such manipulations enabled to investigate inter-trial repetition effects. The square configuration consisted of four words located at each corner. Each word was in a different color: red, blue, yellow, and green. The target word was determined by the color of the fixation cross presented before the stimuli. For example, if the fixation cross was in red, participants knew that the target word would be the one in red. The task was to localize the target word by pressing the relevant keyboard button (for each color, different response keys were assigned, leading to four stimulus-response mappings in total). In a given trial, all the words were in equal length. The design of the study was $2 \times 3 \times 4$ mixed-design with the factors of target location (same, different across consecutive trials), word type (positive, negative, neutral) and configural transitions (big $\rightarrow$ big, big $\rightarrow$ small, small $\rightarrow$ small, small $\rightarrow$ big). The word type was between-subjects variable, and the target location and configural transition variables were within-subjects variables. The dependent variables were reaction time and accuracy rate values.

\section{Results}

The results revealed that the task performance was modulated by the target location, word type and the size of the configuration. When emotional, but not neutral, words were used, participants were faster and more accurate in big configurations compared to smaller ones. When neutral and negative words were used, repetition of the target location across trials led to repetition cost, i.e. slowed the performance. On the other hand, when the target location was different, participants responded faster. 


\section{Discussion}

The current study aimed to investigate the global and local processing and representation of emotional words within the spatial configurations. Results revealed differences in the localization task performance when different word types (negative, positive, neutral) were used in small or big configurations which represent the local and global processes respectively. Repeating the target location across trials slowed the processing speed in the negative and neutral word conditions, whereas changing the target location fastened the processing speed. In addition, in the global to local transition condition (switching from a big to small configuration) positive words were processed slower. This pattern was not observed for the neutral and negative words. Similarly, big $\rightarrow$ big configural transitions led to faster processing speed compared to the small $\rightarrow$ small configural transitions, and this pattern was observed only when the emotional words were used. This can be interpreted as facilitation in the global processing when emotional words were used. Taken together, the present study sheds light on how emotional and neutral words are represented in configurations and on the differences between the global-local level representations in different configural transition conditions. 
Duygular ve farklı duyguların insan davranışına etkisi araştırmacılar tarafından sıklıkla incelenen bir konu olmuştur. Bireylerin duyguları baş etme mekanizmaları olarak kullanması (Folkman ve Moskowitz, 2000), duygu regülasyonu (Walden ve Smith, 1997), duyguların sağlıkta risk alma davranışına etkisi (Peters, Lipkus ve Diefenbach, 2006), duyguların işlenmesinde rol oynayan sinirsel mekanizmalar (Vuilleumier, 2005) gibi farklı konular psikolojinin alt alanlarında incelenmiştir. Bilişsel psikoloji alanında yürütülen birçok çalışmada ise duyguların algı, dikkat, bellek, karar verme gibi farklı bilişsel süreçlere etkisi çeşitli görevlerle incelenmiştir. Bu alanda elde edilen bulgular duygu yüklü uyaranların nötr uyaranlara göre dikkati çekme ve uyaranların işlenme ve hatırlanmasında daha öncelikli olduğunu göstermektedir (Carretie, 2014). Ayrıca yürütülen deney görevinin ve bireysel farklılıkların performansı farklı şekilde etkilediği de ortaya konmuştur (Vuilleumier ve Huang, 2009). Farklı duyguların bilişsel süreçlere etkisinde bulguların tutarlı bir örüntü göstermemesi bu alandaki çalışmaların artmasındaki ihtiyacı ortaya koymaktadır. Bu bağlamda çalışmanın amacı, duyguların görsel mekansal dikkat süreçlerine etkisini incelemektir. Görsel mekansal dikkat süreçleri, konfigürel temsiller ve bu temsillerin global ve yerel seviyelerde işlenmesi özelinde incelenecektir. Geçmiş çalışmalarda görsel mekansal dikkat süreçleri kapsamında konfigürel temsiller incelenmiş ve uyaranların global-yerel seviyede (Navon, 1977) ve konfigürasyonun parçası olarak işlenme ve temsil edilmesine (Gmeindl Nelson, Wiggin ve Reuter-Lorenz, 2011; Jiang, Olson ve Chun, 2000) dair bulgular elde edilmiştir. Ancak, konfigürel temsiller ve görsel mekansal dikkat süreçleri arasındaki etkileşimin farklı duygu koşullarından ne derecede etkilendiği fazla çalışılan bir konu olmamıştır. Duyguların bu süreçlere etkisini incelemek eksik kalan alanda yeni bulgular sunması adına önem taşımaktadır. Bu bağlamda, çalışmada konfigürel temsiller, global-yerel seviyede işlenme ve duygu değişkenleri aynı anda incelenecektir. Kelimelerin oluşturduğu bir konfigürasyonun global seviyede, konfigürasyon parçası olan her kelimenin ise yerel seviyede işlendiği varsayılmaktadır (Navon, 1977). Bu noktadan hareketle konfigürasyon oluşturan duygu yüklü ve nötr kelimelerin işlenmesi ve temsili kıyaslanacaktır. Konfigürel temsiller alanında bugüne dek yürütülen çalışmalarda konfigürasyonlar çoğunlukla görsel şekiller kullanılarak oluşturulmuştur (örn. Gasper, 2004). Yalnızca görsel geometrik şekillerin kullanılması konfigürel temsillerin farklı alanlarda işleyişine dair bilgi sunmamakta ve genelleme yapmayı zorlaştırdığı için yöntemsel açıdan eksiklik taşımaktadır. Bu bağlamda, konfigürasyonların kelimeler kullanarak oluşturulması ve kelimelerin duygusal değerliğinin bir değişken olarak eklenmesi bu 
alanda yeni bir yöntemsel adım olacaktır. Çalışma kapsamında elde edilen bulguların i) kelimelerin konfigürasyonlarda temsil edilmesi, ii) bu temsilin kelime türüne (duygu yüklü, nötr) göre farklılık göstermesi ve iii) kelimelerin farklı konfigürel geçişlerde global ya da yerel seviyede işlenmesi süreçlerine dair literatüre katkı sağlaması beklenmektedir.

\section{Duygular ve Bilişsel Süreçler}

Bilişsel psikoloji alanında duygunun dikkat ve bellek mekanizmaları üzerinde olan etkisi araştırmaların odağındadır (Dolan, 2002; Eich, Kihlstrom, Bower, Forgas ve Niedenthal, 2000, Izard, 1984; LeDoux, 1984; Power ve Dalgleish, 1997). Bulgular, duyguların bilişsel görev performansında hem olumlu hem de olumsuz etkilerini göstermiştir (Brosch, Scherer, Grandjean ve Sander, 2013; Hamann, 2001; Kern, Libkuman, Otani ve Holmes, 2005; Libkuman, Nichols-Whitehead, Griffith ve Thomas, 1999). Duygusal belleğin bilişsel ve sinirsel mekanizmalarının incelendiği bir çalışmada, çeşitli duygu yüklü uyaranların (örn., negatif filmler) nötr uyaranlara kıyasla amigdala aktivasyonunu arttırarak açık belleği etkilediği ve bu şekilde bu uyaranların daha iyi kodlandığı ve geri getirildiği gözlemlenmiştir (Cahill ve ark., 1996; Hamann, 2001). Benzer şekilde, yanıp sönme paradigması (Anderson ve Phelps, 2001), bölünmüş dikkat süreçleri (Kern ve ark., 2005) ve algısal tanımlama görevi (Zeelenberg, Wagenmakers ve Rotteveel, 2006) gibi çeşitli dikkat temelli süreçler incelendiğinde duygu yüklü ve nötr uyaranların işlenmesinde farklılıklar ortaya konmuştur. Bu çalışmalarda farklı bilişsel süreçler incelenmiş olsa da bulgular duygu yüklü uyaranların duygu yüklü olmayanlara göre daha etkili işlendiğini, dolayısıyla daha başarılı performansa yol açtığını göstermiştir.

\section{Konfigürel Temsiller}

$\mathrm{Bu}$ çalışmada duygu yüklü ve nötr kelime işleme süreçlerinin farklı konfigürasyonlarda nasıl değiştiği incelenmiştir. Farklı boyutlardaki konfigürasyonların kullanımı global ve yerel işleme süreçlerini de incelemeyi mümkün kılmaktadır. Konfigürasyon teriminin kökleri Geştalt prensiplerine dayanmaktadır ve bu terim bir bütünü oluşturan parçaların organizasyonu olarak tanımlanabilmektedir (Wertheimer, 1923). Bir uyaran setinde bulunan uyaranların tek tek algılanıp işlenmesi ile uyaranların bir bütün/grup olarak algılanması farklı süreçlerdir (Gmeindl ve ark., 2011). Uyaranların gruplanarak tek parça olarak algılanması uyaranların bir konfigürasyon oluşturmasıyla mümkün olmaktadır. Uyaranlar arası kurulan mekansal ilişki, yani uyaranı çevreleyen mekansal çevrenin etkisi ile konfigürel temsil oluşturulmaktadır. Bir uyaran, çevrede bulunan di- 
ğer uyaranların konumlarına bağlı olarak kodlanmaktadır. Uyaranların tek tek algılanması yerel işleme süreçlerini, konfigürasyon alg1sı/temsili ise global işleme süreçlerini devreye sokmaktadır. Konfigürel temsiller üzerine yapılan çalışmalar konfigürasyonların katılımcılar tarafından otomatik şekilde işlendiğini göstermiştir ve katılımcılara verilen görevlerde konfigürasyonun etkisiyle uyaranların belirli bir özelliğinde yer alan değişimi daha hızlı fark edebildikleri, uyarıcıları daha etkili şekilde kodlayabildikleri ve daha hızlı ve doğru şekilde görsel tarama işlemi gerçekleştirdikleri gözlenmiştir (Boduroglu ve Shah, 2009; Jiang ve ark.,, 2000; Julesz, 1980; Treisman, 1982). Tüm bunlar, uyaranlar arası anlamlı bir algısal düzen olması ve Geştalt prensiplerinin devreye girmesiyle mümkündür. Konfigürel temsillerin, uyaranlar arası ilişki olmayan yani Geştalt prensiplerinin var olmadığı, formsuz şekillere kıyasla katılımcılar tarafından daha hızlı ve doğru algılanması da bunu desteklemektedir (Boduroglu ve Shah, 2009; Jiang ve ark., 2000).

Konfigürel temsiller ile global ve yerel işleme süreçleri birbirleriyle yakından ilgilidir. Global ve yerel süreçler, uyaran setinde yer alan tüm uyaranların daha kapsamlı ve geniş şekilde global eksende (global süreçlerle) veya her uyaranın bireysel olarak yerel eksende (yerel süreçlerle) işlenmesinde rol oynamaktadır. Konfigürel temsillerde ise konfigürasyonun işlenmesi global eksende gerçekleşirken, bütünü oluşturan bireysel uyaranlar yerel eksende işlenmektedir (Kimchi, 1992; Navon, 1977; Navon, 1981). Global ve yerel işleme süreçlerine dair öncü çalışmalarından biri Navon (1977) tarafından yapılmıştır ve katılımcılara gösterilen çeşitli görsel uyaran setlerinin global ve yerel düzlemlerde işlenebildiği ortaya konmuştur. Küçük $\mathrm{H}$ harflerinden oluşan bir $\mathrm{N}$ harfinin işlenmesinde $\mathrm{H}$ harfleri yerel düzeyde, $\mathrm{N}$ harfi ise global düzeyde işlenmiştir. Uyaran setlerinde gerçekleşen global düzeydeki değişimlerin yerel düzeydeki değişikliklerden daha hızlı sürede fark edildiği gözlemlenmiştir ve bu bulgu literatürde 'globalin önceliği’ olarak adlandırılmaktadır (Navon, 1977). Bu konuyla ilgili yapılan birçok çalışmada bütünün yerel parçalara göre daha öncelikli olarak algılandığ hipotezi doğrulanmaktadır (Georgiou-Karistianis ve ark., 2006). Fakat bu yerel özelliklerin tamamen göz ard1 edildiği anlamına gelmemekte, sadece yerel parçalar yerine global özelliklere daha hızlı bir şekilde dikkatin verildiğini göstermektedir (Navon, 1981). Araştırmalara göre görüş açısı, retinal lokasyon, mekansal belirsizlik, yerel element sayısı, maruz kalma süresi ve formun düzgünlüğü gibi faktörler global üstünlük etkisini açıklamaktadır (Hoffman, 1980; Kimchi, 1992; Kinchla ve Wolfe, 1979). Deneysel manipülasyonlar ile global üs- 
tünlük bulgusu tersine çevrilebilmekte, global işlenme önceliği yerini yerel işlenme önceliğine bırakabilmektedir (Kimchi, 1992). Aynı zamanda, sunulan formun global ya da yerel özelliklerinin bozulması veya değiştirilmesi ile dikkatin hangi seviyeye (global-yerel) yönlendirildiğini incelemek mümkündür (Hoffman, 1980; Kinchla ve Wolfe, 1979). Bu çalışmalar, dikkatin yönlendirildiği alanın boyutu ile çeşitli görsel özelliklerin uyaranların global veya yerel seviyede işlenmesini etkilediğini göstermektedir.

\section{Duyguların Global-Yerel İşleme Süreçlerine Etkisi}

Mevcut çalışmanın bir amacı duygudurumun global-yerel süreçlere etkisini incelemektir. Önceki çalışmalar global-yerel işleme süreçlerinin duygunun pozitif ya da negatif olmasına göre farklı etkilendiğini göstermiştir (Baumann ve Kuhl, 2005; Brosch ve ark., 2013; Clore, Gasper ve Garvin, 2001; Gasper ve Clore, 2002; Srinivasan ve Hanif, 2010). Pozitif ve negatif değer taşıyan duygular duygunun döngüsel modeline göre farklılık göstermektedir. Modele göre duygular değerlik ve uyarılma eksenlerinde bir döngü oluştururlar. Değerlik ekseni pozitif (olumlu) - negatif (olumsuz) olarak iki yönlü değer alırken, uyarılma ekseni az - çok değerlerini taşımaktadır (Russell, 2003). Her duygu değerlik ve uyarılma eksenlerinin oluşturduğu uzamsal döngüde bir noktada yerleşmiştir ve bu noktanın konumuna göre her duygunun olumluluk değeri ile bu değerin yol açtığı uyarılma seviyesi değişiklik göstermektedir. Üzüntü gibi negatif duygular dikkat mekanizmalarını daraltır ve bilişsel kaynakların sınırlı kullanımına yol açar. Bu gibi durumlarda, sunulan bilginin bütününden ziyade yerel parçalar baz alınarak işlenir (Clore ve ark., 2001; Clore ve Huntsinger, 2007; Chartrand, van Baaren ve Bargh, 2006; Gable ve Harmon-Jones, 2010). Örneğin, bir çalışmada duygu yüklü ipucu kullanarak katılımcıların global ve yerel işleme performansları karşılaştırılmıştır (Gasper ve Clore, 2002). Katılımcılardan geometrik şekillerden oluşan tek bir geometrik şeklin, global ve yerel özellikleri değişiklik gösteren iki farklı versiyonundan hangisine daha benzer olduğunu belirtmeleri istenmiştir. Sonuçlar pozitif duygu yüklü uyarana maruz kalan gruba kıyasla, negatif duygu yüklü uyarana maruz kalan gruptaki katılımcıların yerel düzlemde yer alan parçayı global düzleme göre daha fazla oranda seçtiklerini göstermiştir. Yazarlar bunu odağın seviyesi hipotezine dayandırarak açıklamıştır (Gasper ve Clore, 2002). 'Odağın seviyesi hipotezi' (levels-of-focus hypothesis) duygunun belirli işlem seviyesini desteklediğini ve o düzeydeki işlemle ilişkili olduğunu savunur (Gasper, 2004; Gasper ve Clore, 2002). Örneğin, mutsuz ruh hali daha küçük ve yerel ayrıntıların işlenmesi ile bağlantılı iken, mutlu ruh hali ise daha büyük ve global düzeydeki işlemler ile bağlantılıdır (Gasper, 2004; Gasper ve 
Clore, 2002). Aynı zamanda, mutluluk gibi pozitif yüklü uyaranlar uyaran setindeki ögenin global düzlemde algılanmasını arttırır, çünkü pozitif duygular negatif duyguların aksine zihinsel esneklik imkanı sunar (Bless, Fiedler ve Forgas, 2006). Frederickson (2001) tarafından öne sürülen "genişlet ve inşa et" kuramı da bu bulguyu desteklemektedir. Kurama göre, pozitif duygudurum bilişsel performanstan daha geniş çapta etkisini göstererek bireylerin mevcut fiziksel ve psikolojik kaynaklarını en etkili şekilde kullanabilmesini ve psikolojik dayanıklılık için elverişli ortamı sağlamaktadır.

\section{Görsel Mekansal Dikkat Süreçleri}

Görsel mekansal dikkat süreçleri, global ve yerel işlemleme süreçleri ile ilintilidir. Bu ilişkiyi ve ilişkinin farklı duygudurumu koşullarında nasıl değiştiğini incelemek çalışmanın temel odağıdır. Bir görsel dikkat türü olan görsel mekansal dikkat kişinin çevresindeki belirli bir alana ya da lokasyona seçici olarak dikkatini yönlendirebilmesini sağlar (Posner, 1980; Tootell ve ark., 1998). Dikkat mekansal alanın belirli bir kısmına odaklanır ve bu şekilde görsel uyaranların seçici şekilde algılanmasına, işlenmesine ve hatırlanmasına izin verir (Awh ve Jonides, 2001). Spot 1şığı kuramına göre, dikkat süreçleri bir spot 1şığı gibi hareket edebilir, boyutu değiştirilebilir ve istenilen mekana doğru yönlendirilebilir (Eriksen ve James, 1986). Buna göre spotun aydınlattığı yani dikkatin yöneldiği alandaki bilgi daha hızlı işlenirken, spot dışında kalan alanlar dikkat alanı dışarısında kaldığından oradaki bilgi işlenemeyecektir (Broadbent, 1982; Eriksen ve Hoffman 1973; Eriksen ve James, 1986). Kısacası, dikkat alanı dışında kalan uyaran(lar)ın işlenebilmesi için spotun yer değiştirmesi gerekmektedir ve bu da görsel mekansal dikkat mekanizmaları ile mümkündür (Posner, 1980; Posner, Snyder ve Davidson, 1980; Remington ve Pierce, 1984; Shulman, Remington ve Mclean, 1979). Literatürdeki çalışmalar, dikkat spotunun performansın iyileşmesi veya kötüleşmesi üzerinde çeşitli faktörlerin etkisi olduğunu göstermiştir. Mevcut çalışma ile yakından ilintili olarak, global ve yerel seviyedeki işlenmede duygusal faktörler ile görsel-mekansal süreçlerin belirleyici bir rolü olduğu bulunmuştur (Broadbent, 1982; Downing, 1985; Eriksen ve Yeh, 1985; Posner, Cohen ve Rafal, 1982). Genel olarak birçok çalışmada, dikkat spotu ne kadar küçükse odaklanılabilecek alan da o kadar küçük olduğundan ve bilişsel kaynakların yeterli gelmesinden dolayı, tepki süresi temelinde performansın iyileştiği (hızlandığı), spot büyüdükçe de performansın kötüleştiği (yavaşladığ1) gösterilmiştir (Egeth, 1977; Eriksen ve James, 1986). Bütün bu çalışmalar göz önünde bulundurularak mevcut çalışmada Eriksen'in spot ışığı kuramı denemeler arası farklı konfigürel geçişlerde dikkatin verildiği alanın büyüklüğü manipüle edilerek test edilecektir. 
Duygunun spot 1şı̆̆ının hareketi ve büyüklüğünün belirlenmesi üzerinde etkisi olduğu da çalışmalarca ortaya konmuştur (Huntsinger, 2013; Wadlinger ve Isaacowitz, 2006; Wegbreit, Franconeri ve Beeman, 2015). Pozitif duygu beraberinde getirdiği bilişsel esneklik ve yaratıcı düşünce ile seçici dikkat üzerinde temel bir etkiye sahiptir (Gasper ve Clore, 2002). Aynı zamanda, pozitif duygu dikkatin kapsamını arttırır, fakat negatif duygu tünel (dar) gibi bir görüşe sebep olduğundan dolayı bu imkanı sunamaz (Niedenthal ve Kitayama, 2013). Bu yüzden, pozitif duygunun mekansal dikkatin spot 1şı̆̆ının genişliğini arttırması beklenmektedir.

$\mathrm{Bu}$ çalışmanın amacı, denemeler arasında boyutu değişen ve bu yolla global ve yerel işleme süreçlerinde farklılı̆ga yol açacağı öngörülen konfigürasyonda sunulan duygu yüklü ve nötr kelimelerin işlenmesindeki süreçleri incelemektir. Deney bloklarında denemeler arasında büyük-küçük, küçük-büyük, büyük-büyük ve küçük-küçük konfigürel geçişlerin varlığ́ global ve yerel görsel dikkat süreçlerinin etkisini incelemeyi mümkün kılacaktır. Ayrıca, farklı kelime türleri (duygu yüklü, nötr) ve konfigürel süreçler arasındaki ilişki hakkında yeni bulgular ortaya konması hedeflenmektedir. Çalışmanın bağımsız değişkenleri denemeler arasında hedef uyaran lokasyonunun aynı veya farklı olması, kelimenin türü (pozitif, negatif, nötr) ve denemeler arası konfigürasyon geçişleri olarak tanımlanmıştır. Bağımlı değişkenler ise tepki doğruluk oranı ve tepki süresidir.

Bir görsel dikkat deney görevinde çeldiriciler arasından tespit edilmesi gereken hedef uyaranın renk, lokasyon, boyut ya da oryantasyon gibi tanımlayıcı özelliklerinin denemeler arasında tekrarlanması veya değişmesinin performansa etkisi farklılık göstermektedir. Denemeler arası hazırlama paradigması ile hedef uyaran özelliğinin değişmesinin performansa etkisini incelemek mümkündür. Hedef uyaran özelliğinin denemeler arasında aynı kalması tepki süresini hızlandırıp doğruluk oranını arttırmaktadır. Ancak hedef uyaran özelliğinin değişmesi tepki süresini yavaşlatıp doğruluk oranını düşürmektedir (Gokce, Müller ve Geyer, 2013; Hillstrom, 2000; Kristjánsson ve Driver, 2008; Maljkovic ve Nakayama, 1994, 1996, 2000;). Hedef uyaran özelliği tekrarlandığında tepki süresinin hızlanmasının sebebi olarak episodik bellek mekanizmasının devreye girmesi ve hedef uyarana dair algı ve dikkat temelli süreçlere tampon uygulaması olarak açıklanmaktadır (Huang ve Pashler, 2005). Mevcut çalışmada da denemeler arası hazırlama paradigması bulgularına dayanarak, bireylerin hedef uyaran lokasyonuna dair örtük bellek temsili geliştirip, hedef uyaranın lokasyonu değişmediğinde uyaranın yer alacağı konumu yordaması beklenmektedir. Dolayısıyla Hipotez $1\left(H_{1}\right)$ aşağıdaki gibidir: 
$H_{1}$ : Hedef uyaran lokasyonunun denemeler arası farklı olduğu koşullarda katılımcıların hedef uyaranın yerini tespit etme $\left(\mathrm{H}_{1 \mathrm{a}}\right)$ doğruluk oranı düşecektir ve $\left(\mathrm{H}_{1 \mathrm{~b}}\right)$ süresi uzayacaktır.

Görsel mekansal dikkat mekanizmalarına dair teoriler bireylerin dikkatini hangi koşullar altında nereye yönlendirdiği konusunda çeşitli açıklamalar sunmaktadır (Wolfe ve Horowitz, 2017). Mekansal dikkat süreçlerinde önemli değişkenlerden biri dikkatin yönlendirildiği alanın büyüklüğüdür (Eriksen ve Hoffman, 1973). Spot 1şı̆̆ı kuramına göre, bu alan ne kadar küçük ise o alanda bulunan uyaranlar daha detaylı şekilde işlenip tepki süresi ve doğruluk oranı düzeyinde deney performansı iyileşmektedir (Eriksen ve James, 1986). Öte yandan dikkatin yönlendirildiği alan büyüdükçe dikkat kaynakları yetersiz kaldığından performansta kötüleşme gözlenmektedir (Egeth, 1977; Eriksen ve James, 1986; Müller, Mollenhauer, Rösler ve Kleinschmidt, 2005). Bu bağlamda, mevcut çalışmada denemeler arasında küçük-küçük konfigürasyon geçişleri ve büyük-büyük konfigürasyon geçişlerinin yer aldığg koşullarda dikkatin yönlendirildiği alan boyutu farklı olacağından performansta farklılık beklenmektedir. Buna bağlı olarak Hipotez $2\left(\mathrm{H}_{2}\right)$ aşağıdaki gibi geliştirilmiştir:

$H_{2}$ : Küçük-küçük konfigürasyon geçişlerinde spot alanı büyük-büyük konfigürasyon geçişlerine kıyasla daha küçük veya dar olacağından hedef uyaranın yerini tespit etme $\left(\mathrm{H}_{2 \mathrm{a}}\right)$ doğruluk oranı artacak ve $\left(\mathrm{H}_{2 \mathrm{~b}}\right)$ süresi kısalacaktır

Konfigürasyonu oluşturan parçaların birbirleriyle oluşturduğu ilişki konfigürel temsilin en önemli unsurudur (Jiang ve ark., 2000). Algisal gruplama ile bireysel uyaranlar (parçalar) anlamlı bir bütün oluşturup bir konfigürasyon içinde temsil edilebilmektedir. $\mathrm{Bu}$ temsil, konfigürasyonların aynı kaldığı koşullarda katılımcıların konfigürasyonu ve konfigürasyonu oluşturan parçaların birbiri ile olan ilişkisini ve konumlarını ilişkilendirmesini mümkün kılmaktadır (Boduroglu ve Shah, 2009). Böylelikle, konfigürel yapı denemeler arası aynı kaldığında deney görevinde kolaylaştırıcı bir etkiye sahip olmaktadır (Gmeindl ve ark., 2011). Mevcut çalışmada konfigürel yapının denemeler arasında değiştiği koşullar yer almaktadır. Buna bağlı olarak geliştirilen Hipotez $3\left(H_{3}\right)$ şu şekildedir:

$H_{3}$ : Denemeler arasında konfigürasyon boyutunun aynı tutulduğu koşullarda (denemeler arası büyük-büyük ve küçük-küçük konfigürasyon geçişleri), konfigürasyonun değiştiği koşullara kıyasla (büyük-küçük ve küçük-büyük konfigürasyon geçişleri) hedef uyaranın yerini tespit etme $\left(\mathrm{H}_{3 \mathrm{a}}\right)$ doğruluk oranı artacak ve $\left(\mathrm{H}_{3 \mathrm{~b}}\right)$ süresi kısalacaktır. 
Son olarak mevcut çalışmanın odağında duygu yüklü ve nötr kelimelerin konfigürasyonda işlenme süreçleri yer almaktadır. Kelimelerin oluşturduğu kare konfigürasyonların boyutunun değişmesi ile (büyük - küçük kare konfigürasyonlar) meydana gelen farklı konfigürasyon geçişlerinin konfigürasyonda bulunan farklı kelimelerin işlenmesini ne derecede etkilediği incelenecektir. 'Odağın seviyesi' prensibinin öne sürdüğü görüşe göre farklı duygular farklı bilgi işleme seviyelerinde etkili olup, global veya yerel seviyede odaklanmayı kolaylaştırarak uyaranın bu (global-yerel) seviyede işlenmesini mümkün kılmaktadır (Baumann ve Kuhl, 2005; Clore ve ark., 2001; Gasper ve Clore, 2002). Pozitif duygunun global seviyede, negatif duygunun ise yerel seviyede odaklanma ve işlenme sürecinde baskın olduğu bulunmuştur. Mevcut çalışmada duygu yüklü kelime işlemenin nötr kelime işlemeye kıyasla farklı konfigürasyon geçişlerinde global ve yerel seviyelerde farklılık göstermesi beklenmektedir. Dolayısıyla Hipotez $4\left(\mathrm{H}_{4}\right)$ aşağıdaki şekilde geliştirilmiştir:

$H_{4}$ : Büyük konfigürasyon geçişlerinde pozitif duygu yüklü kelimelerin global seviyedeki değişimi fark etme kapsamında hedef uyaranın yerini tespit etmede $\left(\mathrm{H}_{4 \mathrm{a}}\right)$ doğruluk oranını arttırması ve $\left(\mathrm{H}_{4 \mathrm{~b}}\right)$ tepki süresini hızlandırması beklenirken, küçük konfigürasyon geçişlerinde negatif duygu yüklü kelimelerin yerel seviyedeki değişimi fark etme kapsamında hedef uyaranın yerini tespit etmede $\left(\mathrm{H}_{4 \mathrm{c}}\right)$ doğruluk oranını arttırması ve $\left(\mathrm{H}_{4 \mathrm{~d}}\right)$ tepki süresini hızlandırması beklenmektedir.

\section{YÖNTEM}

\section{Örneklem}

Katılımcı grubunu İstanbul'da bulunan bir vakıf üniversitesinin lisans öğrencileri oluşturmuştur. Çalışmayı oluşturan üç farklı deney koşulunda farklı katılımcılar yer almıştır. Her deney koşuluna on sekiz kişi katılmıştır ve toplamda elli dört katılımcı (44 kadın, 10 erkek katılımcı) test edilmiştir. Negatif ve nötr deney gruplarının her birinde 15 kadın, pozitif deney grubunda ise 14 kadın katılımcı bulunmaktadır. Katılımcıların yaş ortalaması 21,63 olarak hesaplanmıştır $(S S=1,48)$. Katılımcıların \%85'ini psikoloji bölümü lisans öğrencileri oluşturmuştur, geri kalan katılımcılar başka bölümlerde okuduklarını belirtmişlerdir.

\section{Veri Toplama Araçları}

Uyaranlar. Deneyde konfigürasyon oluşturmak için nötr, pozitif ve negatif kelimeler kullanılmıştır. Her kelime türü için 640 farklı kelime kullanılmıştır. Kelimelerin bir kısmı 
çeşitli veri tabanlarından (Kapucu, Kılıç, Özkılıç ve Sarıbaz, 2018; Tekcan ve Göz, 2005) alınmıştır, geri kalanları ise araştırmacılar tarafından eklenmiştir. Kare konfigürasyonun oluşması için her biri farklı renkte (yeşil, mavi, kırmızı ve sarı) ve farklı lokasyona yerleştirilmiş kelimeler kullanılmıştır. Nötr kelime grubunu oluşturan 640 kelimenin yarısı beş harfli, diğer yarısı altı harfli olacak şekilde seçilmiştir. Pozitif kelime grubundaki 640 kelimeden 172'si 5 harfli, 172'si 6 harfli, 188 tanesi 7 harfli ve 108 tanesi 8 harfli kelimelerden oluşmuştur. Son olarak, negatif kelime grubundaki 640 kelimeden 188 tanesi 5 harfli, 192 tanesi 6 harfli, 164 tanesi 7 harfli ve 96 tanesi 8 harfli kelimelerden oluşmuştur. Bir denemede konfigürasyonda yer alan dört kelimeden hepsi aynı sayıda harfe sahip olacak şekilde tasarlanmıştır. Kelime uzunluğu değişkeninin farklı kelime grupları arasında farklılaşmasını test etmek amacıyla tek yönlü varyans analizi yapılmıştır ve kelime uzunluğunun anlamlı şekilde değişime uğradığı bulunmuştur $(F(2,1121)=266, p<$ .001). Çoklu karşılaştırma (post hoc) testleri pozitif ve negatif kelimelerin nötr kelimelere göre daha uzun olduğunu göstermiştir (her iki $p<.001$ ). Pozitif ve negatif kelimelerin uzunlukları arasında anlamlı bir fark bulunmamıştır $(p>.05)$.

\section{İşlem}

Katılımcılar laboratuvar ortamında ve bilgisayar başında test edilmiştir. Çalışmanın yürütülmesi üniversitenin etik kurulu tarafından onaylanmıştır. HP ProDesk masaüstü bilgisayar uyaran gösterilmesi ve verilen tepkilerin kaydedilmesi için kullanılmıştır. Deneyler PsychoPy Builder (versiyon:1.84.2) yazılımı kullanılarak programlanmıştır (Peirce, 2007). Deney süresince odanın aydınlığı loş seviyede tutulmuştur. Deney yaklaşık kırk beş dakika sürmüştür.

Deneyin yürütülmesinden önce pratik denemeleri sunulmuştur. Pratik denemelerinin amacı katılımcılara deney görevini tanıtmak ve karmaşık olabilecek uyaran-tepki eşleşmelerini öğretmektir. Toplamda 240 deneme pratik amaçlı kullanılmıştır ve elde edilen veri kaydedilmemiştir. Pratik denemelerinin ardından deney yürütülmeye başlanmıştır. Farklı deney koşullarında farklı kelime türleri denekler arası faktör olarak kullanılmıştır. Buna ilave olarak, her koşulda 2 (hedef uyaran lokasyonu) x 2 (konfigürel geçiş) deney-içi desen faktörleri kullanılmıştır. Bu desen, her koşulda ortaya 4 farklı blok çıkarmaktadır. Deneyde her blok türünün iki kere tekrarlanması sonucu her katılımc1 toplamda 8 deney bloğunda performans göstermiştir. Her bir blokta 80 deneme yer almıştır, böylelikle deney toplamda 640 denemeden oluşmuştur. Bloklar arasında katılımcılara ihtiyaçları dahilinde ara verme imkanı sunulmuştur. 
Deneyde yer alan denemelerin akışı şu şekilde olmuştur: "+" fiksasyon işaretinin 1500 milisaniye (ms) süreyle gösterilmesinin ardından kare konfigürasyon 3000 ms süreyle gösterilip lokalizasyon görevi gelmiştir. Konfigürasyonun gösterilmesinden sonra kat1lımcılardan 3000 ms süre içerisinde tepki vermeleri istenmiştir. Sonrasında hata yapılan denemelerde geri bildirim mesaj1 ('HATA!!!' yazısı) ekranda kırmızı renkte 500 ms süreyle gösterilmiştir. Dört kelimeden bir tanesi hedef uyaran olup katılımcılardan bu hedef uyaranın lokasyonunu (örn., sağ/sol - alt/üst köşe) belirtmeleri istenmiştir. Her bir lokasyon için bir klavye tuşu deney boyunca sabit tutulmuştur (sol üst köşe: d, sağ üst köşe: f, sol alt köşe: k ve 'sağ alt köşe: 1). Hedef uyaranın hangi kelime olduğu her denemede değişmiştir ve hedef uyaranın hangi kelime olduğu fiksasyon işaretinin rengi ile rastgele belirlenmiştir. Örneğin, ‘+’ fiksasyon işaretinin rengi mavi ise sonrasında gelen konfigürasyonda mavi renkte yazılı olan kelime o deneme için hedef uyaran olmuştur (Bkz. Şekil 1).

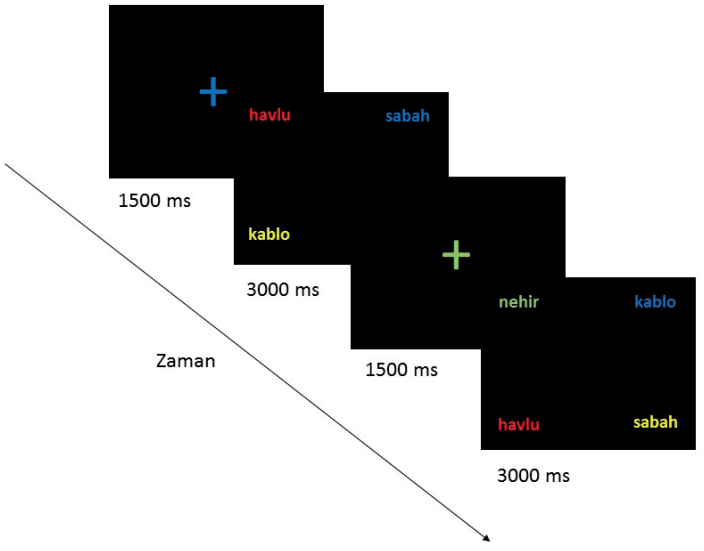

Şekil 1: Deney Akış1

Not: Her deneme fiksasyon '+' işaretinin ekranda belirmesinin ardından dört kelimeden oluşan kare konfigürasyonun gösterilmesiyle devam eder. Fiksasyon işaretinin rengine göre hedef uyaranın yer aldığı konumu belirtir. Şekilde görülen örnekte ilk denemede hedef uyaran kelime mavi renkte olan "sabah" kelimesi, ikinci denemede ise yeşil renkte olan "nehir” kelimesidir. Farklı deneylerde kullanılan kelime türü (duygu yüklü, nötr) değişiklik göstermiştir.

Denemeler arasında hedef uyaranın rengi ve lokasyonu tüm renk ve pozisyon eşleşmelerinde eşit oranda yer almıştır. Diğer bir deyişle dört kelime renginden her biri ile dört konfigürasyon lokasyonundan her biri eşit oranda hedef uyaran tarafindan işgal edilmiştir. Her bir deney bloğunda denemeler arası konfigürasyon geçişleri farklılık göstermiştir. Dört farklı konfigürasyon geçişi (büyük kare $\rightarrow$ küçük kare, küçük kare $\rightarrow$ 
büyük kare, büyük kare $\rightarrow$ büyük kare, küçük kare $\rightarrow$ küçük kare) kullanılmıştır (Bkz. Şekil 2). Denemeler arası büyük-büyük ve küçük-küçük konfigürel geçişlerin oranları eşit tutulmuştur (blok bazında büyük-büyük ve küçük-küçük geçiş oran1 \%50). Kelimelerin oluşturduğu kare konfigürasyonun denemeler arasında boyutunun değişiklik göstermesi ile global ve yerel işlemleme süreçlerini incelemeyi mümkün kılması beklenmiştir. Literatürde yer alan çalışmalarda mevcut çalışmaya benzer değişimler kullanılarak global ve yerel işlemleme süreçleri incelenmiştir (örn., Fink ve ark., 1997; Kimchi ve Palmer, 1982; Lamb ve Robertson, 1990; Navon, 1977).

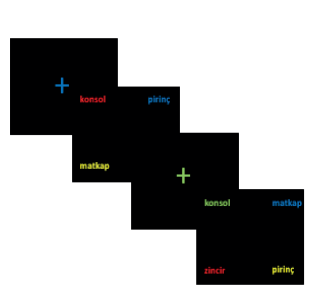

büyük $\rightarrow$ büyük

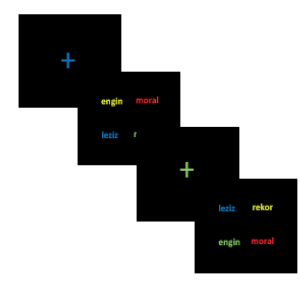

küçük $\rightarrow$ küçük

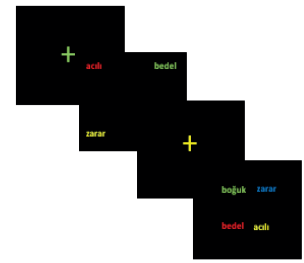

büyük $\rightarrow$ küçük

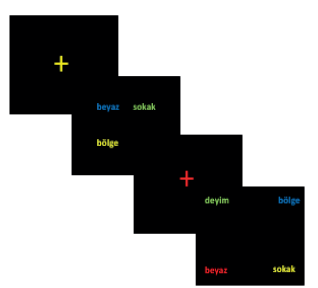

küçük $\rightarrow$ büyük

Şekil 2: Denemeler Arasında Kullanılan Farklı Konfigürel Geçişler

Not: Denemeler arası geçiş (deneme $1 \rightarrow$ deneme 2) fiksasyon işaretinin gösterimi ile gerçekleşir. Fiksasyon işaretinin gösterilmesinden sonra deney koşuluna göre bir önceki deneme ile ayni veya farklı boyutta bir konfigürasyon gösterilir. Denemeler arasında konfigürasyonların aynı kaldığı koşullar (büyük $\rightarrow$ büyük ve küęük $\rightarrow$ küçük konfigürel geçişler) veya farklı olduğu koşullar (büyük $\rightarrow$ küçük ve küçük $\rightarrow$ büyük konfigürel geçişler) konfigürasyonun boyutuna göre belirlenir.

\section{BULGULAR}

Bu çalışmanın tasarımı, 2 denemeler arası hedef uyaran lokasyonu (aynı, farklı) x 2 denemeler arası konfigürel geçiş (büyük-büyük, küçük-küçük) x 3 kelime türü (negatif, pozitif, nötr) faktörlerini kapsayan karış1k desenli faktöriyel desendir. Şekil 2'de belirtildiği gibi konfigürel geçiş değişkeni dört kategorili bir değişkendir. Ancak büyük kare $\rightarrow$ küçük kare ve küçük kare $\rightarrow$ büyük kare koşulları analizlere dahil edilmemiştir. Bunun sebebi, bu koşullarda hedef uyaran lokasyonu konfigürasyonda aynı olsa dahi (örn., sağ üst köşe) büyük ve küçük kare konfigürasyonlarda Kartezyan koordinat sisteminde ekranın X-Y koordinatlarında farklı bir konumda olacağından sonuçları yorumlarken karıştırıcı bir faktör olacak olmasıdır. Bu sebeple analize büyük kare $\rightarrow$ büyük kare ve küçük kare $\rightarrow$ küçük kare kategorileri dahil edilmiştir. Yalnızca $\mathrm{H}_{3}$ 'ü test etmek amacıy- 
la konfigürasyonun aynı kaldığı (büyük-büyük, küçük-küçük geçişler) ile konfigürasyonun farklılaştığı (büyük-küçük, küçük-büyük geçişler) koşullar karşılaştırılmıştır. Hedef uyaran lokasyonu ve konfigürel geçiş değişkenleri denek içi desen, kelime türü ise denekler arası desen faktörü olarak tasarlanmıştır. Analiz edilen bağımlı değişkenler tepki süresi ve doğruluk oranı olmuştur. Hipotezleri test etmek için karışık desenli varyans analizi yürütülmüş̧ür.

Deney koşullarında genel doğruluk oranı \%91 olarak hesaplanmıştır. $\mathrm{H}_{1}{ }^{\prime} \mathrm{i}$ sınamak için hedef uyaran lokasyonunun denemeler arası farklı olduğu koşullarda katılımcıların hedef uyaranın yerini tespit etme süresi ve doğruluk oranı incelenmiştir. Doğruluk oranı ile bulgular, hedef uyaran lokasyonunun anlamlı bir ana etkisi olduğunu göstermiştir, $\left(F(1,51)=8.90, p=.004, \eta^{2}=.02\right)$. Çoklu karşılaştırma analizi, hedef uyaranın lokasyonunun tekrarlandığı (\%94.2) koşulda, değiş̧mesine (\%92.3) kıyasla deney görevinin daha başarılı şekilde yürütüldüğünü göstermektedir. $\mathrm{H}_{2}$ ve $\mathrm{H}_{3}$ 'ün sınanması amacıyla doğruluk oranı incelenmesi sonucu konfigürel geçiş, konfigürasyon değişimi, kelime türü ana etkileri ile bu değişkenler arasında anlamlı etkileşim bulunmamıştır $(p>.05)$. Bulgular, doğruluk oranı değişkeni kapsamında sadece Hipotez 1a'nın desteklendiğini, Hipotez 2a, 3a ve 4a'nın desteklenmediğini göstermektedir.

Hipotez 1b, 2b, 3b ve 4b'yi test etmek amacıyla tepki süresi bağımlı değişkeni üzerine analizler yürütülmüş ve bu analizlere katılımcıların doğru tepki verdiği denemeler dahil edilmiştir. $\mathrm{H}_{1}$ 'in test edilmesi amacıyla hedef uyaran lokasyonunun denemeler arası farklı olduğu koşullarda katılımcıların hedef uyaranın yerini tespit etme süresini incelemek için yapılan analiz, hedef uyaranın lokasyonunun tepki süresi üzerinde anlamlı bir ana etkisi olduğunu göstermiştir, $\left(F(1,51)=19.43, p<.001, \eta^{2}=.22\right)$ ve $\mathrm{H}_{1 \mathrm{~b}}$ desteklenmiştir. Denemeler arasında hedef uyaranın lokasyonunun aynı kalması (799 ms) hedef uyaranın lokasyonunun değişmesine (775 ms) kıyasla tepki süresini uzattı̆̆ bulunmuştur.

$\mathrm{H}_{2}$ 'nin test edilmesi kapsamında hedef uyaranın lokasyonundan bağımsız olarak denemeler arasında küçük-küçük konfigürasyon geçişleri ile büyük-büyük konfigürasyon geçişlerinde tepki sürelerinin kıyaslanması amacıyla yapılan analiz konfigürel geçişin (büyük-büyük ve küçük-küçük geçişler) tepki süresi üzerinde anlamlı bir ana etkisi olduğunu göstermiştir, $\left(F(1,51)=65.84, p<.001, \eta^{2}=.56\right)$. Denemeler arasında büyük $\rightarrow$ büyük konfigürel geçişler $(838 \mathrm{~ms})$ küçük $\rightarrow$ küçük geçişlere $(882 \mathrm{~ms})$ göre daha hızlı tepki süresine yol açmıştır. Bu bulgu kapsamında varsayılan etki gözlenmediğin- 
den $\mathrm{H}_{2 \mathrm{~b}}$ desteklenmemiştir. Denemeler arasında konfigürel geçiş büyük $\rightarrow$ büyük olarak sunulduğu koşulda gerçekleşen tepki süresi (770 ms) küçük $\rightarrow$ küçük geçiş koşuluna göre (804 ms) daha hızlı olarak tespit edilmiştir.

$\mathrm{H}_{3}$ 'ü sınamak için konfigürel değişikliklerin etkisini test etmek amacıyla konfigürasyonun denemeler arasında aynı kaldığı büyük-büyük, küçük-küçük geçişleri ile konfigürasyonun farklılaştığı büyük-küçük, küçük-büyük geçiş koşulları hedef uyaranın yerini tespit etme süresini incelemek amacıyla karşılaştırılmıştır. Bulgular, konfigürel geçişin tepki süresi üzerinde anlamlı bir etkisi olduğunu göstermiştir, $(F(1,51)=9.68, p$ $\left.=.003, \eta^{2}=.005\right)$. Konfigürasyon denemeler arasında aynı kaldığında (801 ms) (büyük $\rightarrow$ büyük veya küçük $\rightarrow$ küçük) değişmesine (784 ms) (büyük $\rightarrow$ küçük veya küçük $\rightarrow$ büyük) kıyasla daha yavaş işlendiği görülmüştür. Bu bulgu kapsamında konfigürel değişikliklerin varsayılan tepki süresini azaltma etkisi gözlenmediğinden $\mathrm{H}_{3 \mathrm{~b}}$ desteklenmemiştir.

$\mathrm{H}_{4}$ 'ü sınama amacıyla konfigürel geçişler ile kelime türünün tepki süresine etkisi incelenmiş ve kelime türü ile konfigürel geçiş arasında marjinal seviyede anlamlı bir etkileşim bulunmuştur, $\left(F(1,51)=2.56, p=.08, \eta^{2}=.003\right.$; Bkz. Şekil 3). Nötr ve negatif kelimelerden ziyade sadece pozitif kelimeler kullanıldığı koşulda anlamlı bir farklılaşma yönünde eğilim gözlemlenmiştir. $\mathrm{Bu}$ bulgu, $\mathrm{H}_{4 \mathrm{~b}}$ 'nin kısmen desteklendiğini, $\mathrm{H}_{4 \mathrm{~d}}$ 'nin ise desteklenmediğini göstermektedir.

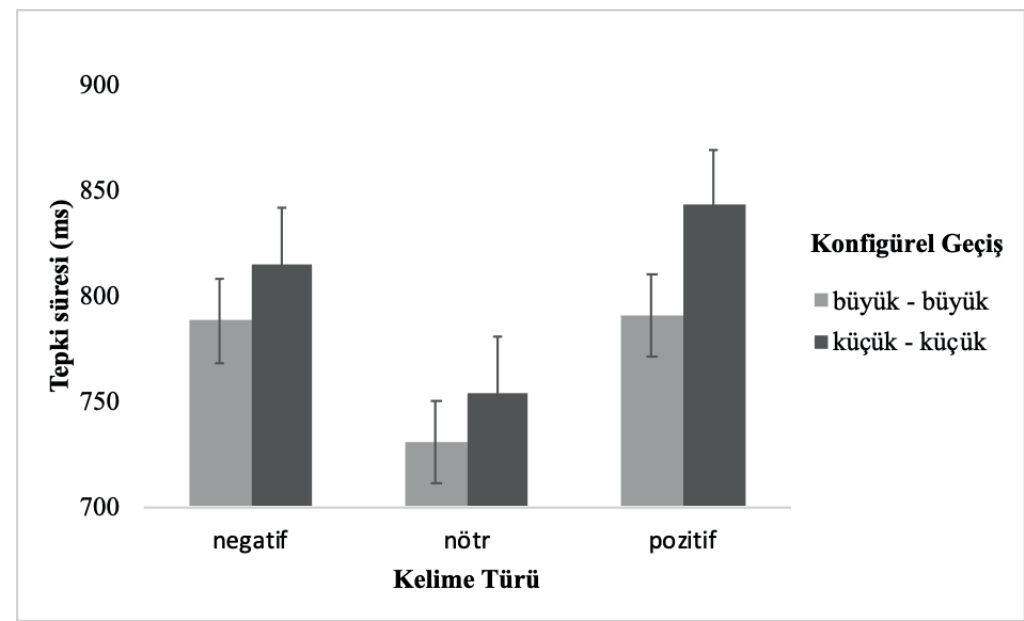

Şekil 3: Konfigürel Geçiş ve Kelime Türleri Arasındaki İlişki

Not. Büyük-büyük ve küçük-küçük konfigürel geçişlerde pozitif ve nötr kelimelerin işlenme performansı (tepki süresi) milisaniye ölçümüyle değerlendirilmiştir $(*=p<.001)$ (Hipotez 4 bulguları). 
Analizler sonucunda hipotezlerden bağımsız olarak ortaya çıkan bulgulardan biri hedef uyaranın lokasyonunun aynı veya farklı olduğu durumlar ile konfigürel geçişler arasında anlamlı bir etkileşim olduğunu göstermiştir, $\left(F(1,51)=4.52, p=.038, \eta^{2}=.002\right.$; Bkz. Şekil 4). Hedef uyaranın lokasyonunun aynı kalması veya değişmesi konfigürel geçiş koşulları arasındaki farkta değişime yol açmıştır. Büyük $\rightarrow$ büyük geçişler, küçük $\rightarrow$ küçük geçişlere göre daha kısa tepki süresine yol açsa da iki koşul arasındaki fark hedef uyaran lokasyonunun aynı kalması (24 ms) veya değişmesine (45 ms) göre değişim göstermektedir. Kelime türü, konfigürel geçiş ve lokasyon değişkenleri arasında anlamlı bir etkileşim bulunmamıştır $\left(F(2,51)=.37, p>.05, \eta^{2}=.001\right)$.

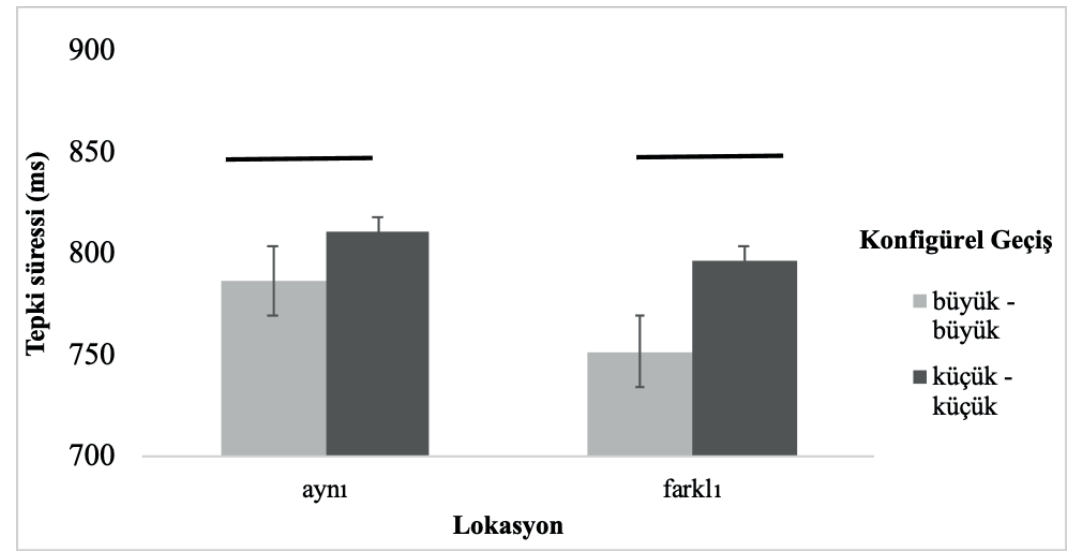

Şekil 4: Konfigürel Geçiş ve Hedef Uyaran Lokasyonu Arasındaki İlişki

Not. Büyük-büyük ve küçük-küçük konfigürel geçişlerde ve hedef uyaranın lokasyonunun aynı kaldığı veya farklı olduğu denemelerde lokalizasyon deney görevi performansı milisaniye ölçümüyle değerlendirilmiştir $(*=p<.05)$ (Hipotez 1 ve 2 bulguları).

Hipotezlerden bağımsız olarak ortaya çıkan bir diğer bulgu, hedef uyaranın yerini tespit etme süresinin kelime türüne (pozitif, negatif, nötr) göre farklılaştığ 1 olmuştur. Kelime türünün anlamlı bir ana etkisi bulunmamıştır, $F(2,51)=2.09, p>.05, \eta^{2}=.06$. Ancak hedef uyaranın lokasyonu ve kelime türü arasında anlamlı bir etkileşim etkisi tespit edilmiştir, $F(1,51)=8.85, p<.001, \eta^{2}=.20$. Negatif kelimelerin işlenmesi sırasında hedef uyaranın lokasyonunun değişmesi (788 ms), aynı kalması (838 ms) koşuluna göre tepki süresini hızlandırmıştır $(t(51)=4.20, p=.001)$. Aynı örüntü, nötr kelimelerin işlenmesi sırasında da ortaya çıkmıştır, hedef uyaranın lokasyonunun değişmesi (794 ms) aynı kaldığı koşula (858 ms) göre tepki süresini hızlandırmıştır $(t(51)=4.32$, $p$ $<.001)$. Bu örüntü pozitif kelimeler için gözlenmemiştir ( $p>$.05; Bkz. Şekil 5). 


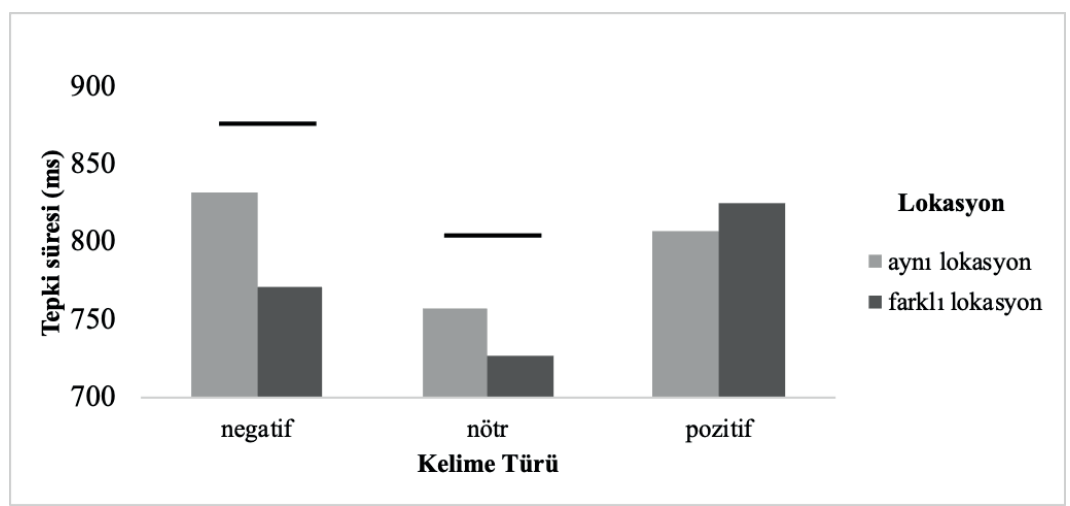

Şekil 5: Hedef Uyaranın Lokasyonu ve Kelime Türü Arasındaki Etkileşim Etkisi

Not. Hedef uyaranın lokasyonunun aynı kaldığı veya farklı olduğu denemelerde negatif, pozitif ve nötr kelimelerin işlenme performansı (tepki süresi) milisaniye ölçümüyle değerlendirilmiştir $(*=p<.001)$. (Hipotez 1 ve 4 bulgular1).

\section{TARTIŞMA}

Bu çalışmada belirli bir konfigürasyonda sunulan farklı kelime türlerinin (duygu yüklü, nötr) işlenme süreçleri global-yerel işlemleme seviyelerinde incelenmiştir. Sonuçlar, konfigürel temsillerin duygu yüklü ve nötr kelimelerin işlenmesini farklı şekilde etkilediğini ortaya koymuştur. Çalışmada test edilen hipotezlerden biri, duygu yüklü kelimeler ile nötr kelimelerin işlenmesinin farklı konfigürel geçişlerde işlenirken değişiklik göstermesidir. Büyük kare konfigürasyon kullanılarak global, küçük kare konfigürasyon kullanılarak ise yerel işlenme süreçleri incelenmiştir. Denemeler arasında konfigürasyonun büyükten küçüğe geçişi karşılaş̧ırıldığında (global $\rightarrow$ yerel geçiş) pozitif kelimelerin işlenmesinin yavaşladığı bulunmuştur, ancak aynı örüntü negatif ve nötr kelimeler için bulunmamıştır. Bu bulguyu pozitif kelimelerin işlenmesinde spot ışığ kuramı ile açıklamak mümkündür. Pozitif kelimelerin işlenmesi sırasında dikkatin yönlendirildiği alanın büyüklügü̈, yani global işleme seviyesi bir farklılaşmaya yol açmaktadır (Gasper, 2004). Hedef uyaranın lokasyonu denemeler arasında aynı ekran konumunda sunulup tekrarlandığında, nötr ve negatif kelimelerin kullanıldığı deney koşullarında tepki süresinin yavaşlamasına yol açmıştır. Bu bulgu, çalışma öncesi öngörülen katılımcıların örtük bellek temsili geliştirip hedef uyaranın yer alacağı konumu yordaması hipotezine zıt düşmektedir. Bunun sebebi olarak literatürde bulunan tekrar kaynaklı tepki süresinde görülen yavaşlama etkisi gösterilebilir (Anderson ve Folk, 2012; Chao, 2011). Ayrıca, geri dönüş ketlemesi kuramı da dikkatin yeni hedef uyaran lokasyonuna yöneltilmesi durumuna 
açıklık getirmiştir (Klein ve MacInnes, 1999; Pan, Wu ve Zhang, 2017; Posner ve Cohen, 1984). Bu kavrama göre, katılımcılar daha önceden gördükleri uyaranın lokasyonuna yakın bir lokasyondaki uyarana maruz kaldıklarında tepkilerinde bir gecikme meydana gelecektir, çünkü katılımcılar eski alan yerine yeni bir alana dikkatlerini yönelteceklerdir (Itti ve Koch, 2001; Kingstone ve Pratt, 1999; Klein, 2000). Chao (2011) mekansal ipuçlama yöntemi kullanarak denemeler arasında hedef uyaran konumunun tekrarlanmasının geri dönüş ketlemesi ile ilişkisini incelenmiştir. Chao (2011) geri dönüş ketlemesi ile tekrar kaynaklı tepki süresinde görülen yavaşlama etkilerinin ortak mekanizma tarafından yönetildiği fikrini ortaya sürmüştür. Mevcut çalışmada nötr ve negatif hedef uyaranların aynı ekran konumunda yer alması koşulunda tepki süresinin uzaması benzer mekanizma ile açıklanabilir. Bu koşullarda katılımcılar hedef uyaranın bulunduğu konuma öncelik vermeyerek dikkatlerini farklı konuma yönlendirdikten sonra hedef uyaran konumuna yönelmişlerdir ve bu tepki süresinin uzamasına yol açmıştır.

Çalışmadan elde edilen bir diğer bulgu ise büyük $\rightarrow$ büyük konfigürasyon geçişlerinde tepki sürelerinin küçük $\rightarrow$ küçük geçişlerine kıyasla daha hızlı olmasıdır. Bu sonuca göre global işlemleme yerel işlemlemeye kıyasla daha kısa sürede tamamlanmıştır. Sunulan hipotezlerden biri spot alanı ne kadar küçükse mevcut bilişsel kaynaklar o alana yönlendirileceği için performansın o kadar avantajlı (hızlı) olacağı yönündeydi (Egeth, 1977; Eriksen ve James, 1986); ancak bulgular bu hipotezi desteklememektedir. Küçük $\rightarrow$ küçük konfigürasyon geçişlerinde tepki süresinin yavaşlaması ve bu geçişlerde spot 1şığı altına düşen dikkat alanının dar olması, bilişsel kaynakların uyaranların (negatif kelimelerin) tümünün derinlemesine işlenmesi ve bu sürecin tepki süresinin yavaşlamasına yol açması ile açıklanmaktadır (Broadbent, 2013; Carrasco, 2011). Bu sonucun özellikle negatif kelime koşulunda elde edilmesi global ve yerel işleme süreçlerinin etkisinden ziyade, negatif kelimelerin işlenmesinin pozitif ve nötr kelimelere kıyasla farklılık gösterdiğini desteklemektedir. Büyük $\rightarrow$ büyük konfigürasyon (global seviye) geçişlerine kıyasla, küçük $\rightarrow$ küçük konfigürasyon geçişlerinde (yerel seviye) katılımcılar negatif kelimeleri okumaya daha fazla dikkat kaynaklarını yöneltmiş, bu da tepki süresinde yavaşlamaya yol açmış olabilir. Ancak katılımcıların deney sonundaki hatırlama performansı kelime tanıma göreviyle test edilmediğinden bu spekülatif bir yorumdur; negatif kelimelerin pozitif ve nötr kelimelere göre daha yüksek oranda hatırlandığ1na dair veri bulunmamaktadır. Aynı durum sebebiyle büyük $\rightarrow$ büyük konfigürasyon geçişlerinin bulunduğu denemelerdeki kelimeler, küçük konfigürasyonlara kıyasla daha 
az oranda okunmuş ve katılımcıların duygu yüklü kelimeleri işlemeye yeterince vakit ayırmayıp deney görevini yapmayı öncelikli tutmuş olabileceği düşünülmüştür. Lokalizasyon görevinin kelimeleri ayrıntılı şekilde okumadan hedef uyaranı belirten rengin saptanması ile yapılmasının, katılımcılar tarafından iyi performans göstermek için bulunmuş bir strateji olabileceği varsayılmıştır. Dolayısıyla bu varsayım, katılımcıların deney boyunca hedef uyaranın lokasyonunu tespit etmek için bir strateji belirleyip diğer uyaranlara dikkat etmemiş ve kelimeleri okumamış olabileceklerini akla getirmiştir. $\mathrm{Bu}$ sebeple katılımcıların kelimeleri dikkatlice okuyup okumadığını test etmek için kelimenin rengi faktörünün duygu yüklü ve nötr kelimelerin lokalize edilmesine bir etkisinin olup olmadığı incelenmiştir. Örneğin, hedef uyaranın kırmızı renkte negatif kelime olduğu ile kırmızı renkte pozitif kelime olduğu koşullar arasında anlamlı bir fark çıkması bazı kelimelerin (örn., negatif) katılımcılar tarafından okunmadığını gösterebilir. Tepki süresinin kelimenin rengi ve kelimenin türüne göre analiz edilmesi sonucu renk faktörünün anlamlı bir ana etkisi bulunmuştur $(\mathrm{p}<.001)$ ancak kelime türünün bir etkisi $(p>$ $.05)$ ve kelime türü x kelime rengi arasında bir etkileşim $(p>.05)$ olmamıştır. Yani, farklı renkler tepki süresini etkilese de rengin duygu yüklü ve/ya nötr kelimelerin işlenmesine bir etkisi olmadığı saptanmıştır. Bu bulgu, kelimelerin yeterince işlenmemiş olabileceği tezini çürütmektedir.

Çalışmanın örnekleminin büyük kısmını kadın katılımcılar oluşturmuştur. Literatürde konfigürel temsillerin kadın/erkek cinsiyetinde farklılaştığını inceleyen çalışma bulunmasa da (yüzlerin işlenmesi üzerine birtakım çalışmalar olsa da mevcut çalışmanın odağı dışında kalmaktadır), diğer görsel dikkat ve mekansal dikkat süreçlerinde kadın ve erkek katılımcıların farklılaştığını gösteren çalışmalar mevcuttur [(örneğin eğik çizginin açısını tahmin etme (Collaer ve Nelson, 2002); zihinsel döndürme (Geiser, Lehmann ve Eid, 2008); görsel-mekansal imgeleme (Loring-Meier ve Halpern 1999)]. Bulgular farklı görsel-mekansal görevlerde kadın katılımcıların performansının erkeklere göre daha zayıf olduğunu göstermiştir. Mevcut çalışmada kadın katılımcılar çoğunlukta olduğundan bu hususun sonuçların yorumlanmasında ve genellendirilmesinde dikkate alınması faydalı olacaktır.

Bu çalışmada duygu yüklü kelimelerin işlenmesindeki süreçler farklı konfigürasyonlar kullanılarak ve denemeler arası hedef kelimenin lokasyonu manipüle edilerek incelenmiştir. Sonuçlara göre katılımcıların performansları hedef uyaran lokasyonuna, duygu tipine ve konfigürasyona bağlı olarak değişim göstermiştir. Spesifik olarak, hedef 
uyaran lokasyonunun denemeler arası tekrarı negatif ve nötr kelimeler için tepki süresinde uzamaya sebep olmuştur ve katılımcılar hedef uyaran lokasyonu değiştiği zaman daha hızlı tepki vermişlerdir. Sonuç olarak bu çalışma konfigürel temsillerin duygu yüklü ve nötr kelimelerin işlenmesini farklı şekilde etkilediğini ortaya koymuştur. Çalışmanın bulgularından yola çıkarak gelecek çalışmalarda farklı duygu yüklerini içeren uyaranlar kullanarak pozitif-negatif duygu kategorilerindeki ayrık duyguların (örn., tiksinme, korku, öfke, heyecan, tutku vb.) etkisini incelemek bu bilişsel süreç hakkında daha detaylı bilgi sunacaktır. Ayrıca, ileriki çalışmalarda duygu yüklü kelimelerin işlenmesini farklı bilişsel görev ve paradigmalarda inceleyip karşılaştırarak eyleme özgü bir etkinin olup olmadığının test edilmesi önerilmektedir.

Hakem Değerlendirmesi: Dış bağımsız.

Çıkar Çatışması: Yazarlar çıkar çatışması bildirmemiştir.

Finansal Destek: Yazarlar bu çalışma için finansal destek almadığını beyan etmiştir

Peer-review: Externally peer-reviewed.

Conflict of Interest: The authors have no conflict of interest to declare.

Grant Support: The authors declared that this study has received no financial support.

\section{Kaynakça}

Anderson, B. A. ve Folk, C. L. (2012). Dissociating location-specific inhibition and attention shifts: Evidence against the disengagement account of contingent capture. Attention, Perception and Psychophysics, 74(6), 1183-1198.

Anderson, A. K. ve Phelps, E. A. (2001). Lesions of the human amygdala impair enhanced perception of emotionally salient events. Nature, 411(6835), 285-305.

Awh, E. ve Jonides, J. (2001). Overlapping mechanisms of attention and spatial working memory. Trends in Cognitive Sciences, 5(3), 119-126.

Baumann, N. ve Kuhl J. (2005). Positive affect and flexibility: Overcoming the precedence of global over local processing of visual information. Motivation and Emotion, 29(2), 123-134.

Bless, H., Fiedler, K., ve Forgas J. P. (2006). Mood and the regulation of information processing and behavior. J. P. Forgas (Eds.), Affect in social thinking and behavior içinde. New York: Taylor \& Francis Psycology Press.

Boduroglu, A. ve Shah, P. (2009). Effects of spatial configurations on visual change detection: An account of bias changes. Memory \& Cognition. 37(8), 1120-1131.

Broadbent, D. E. (1982). Task combination and selective intake of information. Acta Psychologica, 50(3), 253-290.

Broadbent, D. E. (2013). Perception and communication. Oxford: Pergamon Press.

Brosch, T., Scherer, K. R., Grandjean, D. M. ve Sander, D. (2013). The impact of emotion on perception, attention, memory, and decision-making. Swiss Medical Weekly, 143, 1-10. 
Cahill, L., Haier, R. J., Fallon, J., Alkire, M. T., Tang, C., Keator, D. ve Mcgaugh, J. L. (1996). Amygdala activity at encoding correlated with long-term, free recall of emotional information. Proceedings of the National Academy of Sciences, 93(15), 8016-8021.

Carrasco, M., (2011). Visual attention: The past 25 years. Vision Research, 51(13), 1484-1525.

Carretie, L. (2014). Exogenous (automatic) attention to emotional stimuli: a review. Cognitive, Affective and Behavioural Neuroscience, 14(4), 1228-1258

Chao, H. F. (2011). Target-to-target repetition cost and location negative priming are dissociable: Evidence for different mechanisms. Journal of Experimental Psychology: Human Perception and Performance, 37(4), 1060-1074.

Chartrand, T. L., van Baaren, R. B. ve Bargh, J. A. (2006). Linking automatic evaluation to mood and information processing style: Consequences for experienced affect, impression formation, and stereotyping. Journal of Experimental Psychology: General, 135(1), 58-70.

Clore, G. L., Gasper, K. ve Garvin, E. (2001). Affect as information. J. P. Forgas (Ed.), Handbook of affect and social cognition içinde (s. 121-144). Mahwah, NJ.: Lawrence Erlbaum Associates.

Clore, G. L. ve Huntsinger, J. R. (2007). How emotions inform judgment and regulate thought. Trends in Cognitive Sciences, 11(9), 393-399.

Collaer, M. L. ve Nelson, J. D. (2002). Large visuospatial sex difference in line judgment: Possible role of attentional factors. Brain and Cognition, 49(1), 1-12.

Dolan, R. J. (2002). Emotion, cognition, and behavior. Science, 298(5596), 1191-1194.

Downing, C. J. (1985). The spatial structure of visual attention. Mechanisms of Attention: Attention and Performance, 11, 171-187.

Egeth, H. (1977). Attention and preattention, The Psychology of Learning and Motivation, 11, 277-320.

Eich, E., Kihlstrom, J. F., Bower, G. H., Forgas, J. P. ve Niedenthal, P. M. (2000). Cognition and emotion. UK: Oxford University Press.

Eriksen, C. W. ve Hoffman, J. E. (1973). The extent of processing of noise elements during selective encoding from visual displays. Perception \& Psychophysics, 14(1), 155-160.

Eriksen, C. W. ve James, J. D. S. (1986). Visual attention within and around the field of focal attention: A zoom lens model. Perception \& Psychophysics, 40(4), 225-240.

Eriksen, C. W. ve Yeh, Y. Y. (1985). Allocation of attention in the visual field. Journal of Experimental Psychology: Human Perception and Performance, 11(5), 560-583.

Fink, G. R., Halligan, P. W., Marshall, J. C., Frith, C. D., Frackowiak, R. S. ve Dolan, R. J. (1997). Neural mechanisms involved in the processing of global and local aspects of hierarchically organized visual stimuli. Brain: A Journal of Neurology, 120(10), 1779-1791.

Folkman, S.ve Moskowitz, J. T. (2000). Stress, positive emotion, and coping. Current Directions in Psychological science, 9(4), 115-118.

Gable, P. ve Harmon-Jones, E. (2010). The blues broaden, but the nasty narrows: Attentional consequences of negative affects low and high in motivational intensity. Psychological Science, 21(2), 211-215.

Gasper, K. (2004). Do you see what I see? Affect and visual information processing. Cognition and Emotion, 18(3), 405-421.

Gasper, K. ve Clore, G. L. (2002). Attending to the big picture: Mood and global versus local processing of visual information. Psychological Science, 13(1), 34-40.

Geiser, C., Lehmann, W. ve Eid, M. (2008). A note on sex differences in mental rotation in different age groups. Intelligence, 36(6), 556-563.

Georgiou-Karistianis, N., Tang, J., Mehmedbegovic, F., Farrow, M., Bradshaw, J. ve Sheppard, D. (2006). Age-related differences in cognitive function using a global local hierarchical paradigm. Brain Research, 1124(1), 86-95. 
Gmeindl, L., Nelson, J. K., Wiggin, T. ve Reuter-Lorenz, P. A. (2011). Configural representations in spatial working memory: modulation by perceptual segregation and voluntary attention. Attention, Perception \& Psychophysics, 73, 2130-2142.

Gokce, A., Müller, H. J. ve Geyer, T. (2013). Positional priming of pop-out is nested in visuospatial context. Journal of Vision, 13(3), 12-32.

Hamann, S. (2001). Cognitive and neural mechanisms of emotional memory. Trends in Cognitive Sciences, 5(9), 394-400.

Hillstrom, A. P. (2000). Repetition effects in visual search. Perception \& Psychophysics, 62, 800-817.

Hoffman, J. E. (1980). Interaction between global and local levels of a form. Journal of Experimental Psychology: Human Perception and Performance, 6(2), 200-222.

Huang, L. Q. ve Pashler, H. (2005). Expectation and repetition effects in searching for featural singletons in very brief displays. Perception \& Psychophysics, 67(1), 150-157.

Huntsinger, J. R. (2013). Does emotion directly tune the scope of attention? Current Directions in Psychological Science, 22(4), 265-270.

Itti, L. ve Koch, C. (2001). Computational modelling of visual attention. Nature Reviews Neuroscience, 2(3), 180-194.

Izard, C. E. (1984). Emotion-cognition relationships and human development. Emotions, Cognition, and Behavior, 1, 17-37.

Jiang, Y., Olson, I. R. ve Chun, M. M. (2000). Organization of visual short-term memory. Journal of Experimental Psychology: Learning, Memory, and Cognition, 26(3), 670-683.

Julesz, B. (1980). Spatial nonlinearities in the instantaneous perception of textures with identical power spectra. Philosophical Transactions of the Royal Society of London, Series B, Biological Sciences, 290(1038), 83-94.

Kapucu, A., Kılıç, A., Özkılıç, Y. ve Sarıbaz, B. (2018). Turkish emotional word norms for arousal, valence, and discrete emotion categories. Psychological Reports. doi: 10.1177/0033294118814722

Kern, R. P., Libkuman, T. M., Otani, H. ve Holmes, K. (2005). Emotional stimuli, divided attention, and memory. Emotion, 5(4), 390-408.

Kimchi, R. (1992). Primacy of wholistic processing and global/local paradigm: A critical review. Psychological Bulletin, 112(1), 10-24.

Kimchi, R. ve Palmer, S.E. (1982). Form and texture in hierarchically constructed patterns. Journal of Experimental Psychology: Human Perception and Performance, 8, 521-535.

Kinchla, R. A. ve Wolfe, J. M. (1979). The order of visual processing: "Top-down”, "bottom-up," or "middle-out". Perception \& Psychophysics, 25(3), 225-231.

Kingstone, A. ve Pratt, J. (1999). Inhibition of return is composed of attentional and oculomotor processes. Perception \& Psychophysics, 61(6), 1046-1054.

Klein, R. M. (2000). Inhibition of return. Trends in Cognitive Sciences, 4(4), 138-147.

Klein, R. M. ve MacInnes, W. J. (1999). Inhibition of return is a foraging facilitator in visual search. Psychological Science, 10(4), 346-352.

Kristjánsson, Á. ve Driver, J. (2008). Priming in visual search: Separating the effects of target repetition, distractor repetition and role reversal. Vision Research, 48, 1217-1232.

Lamb, M. R. ve Robertson, L. C. (1990). The effect of visual angle on global and local reaction times depends on the set of visual angles presented. Perception \& Psychophysics, 47(5), 489-496.

LeDoux, J. E. (1984). Cognition and emotion. Handbook of cognitive neuroscience içinde (s. 357-368). Springer, Boston, MA.

Libkuman, T. M., Nichols-Whitehead, P., Griffith, J. ve Thomas, R. (1999). Source of arousal and memory for detail. Memory \& Cognition, 27(1), 166-190. 
Loring-Meier, S. ve Halpern, D. F. (1999). Sex differences in visuospatial working memory: Components of cognitive processing. Psychonomic Bulletin \& Review, 6(3), 464-471.

Maljkovic, V. ve Nakayama, K. (1994). Priming of pop-out I: Role of features. Memory \& Cognition, 22(6), 657-672.

Maljkovic, V. ve Nakayama, K. (1996). Priming of pop-out-out II. The role of position. Perception \& Psychophysics, 58(7), 977-991.

Maljkovic, V. ve Nakayama, K. (2000). Priming of pop-out III. A short term implicit memory system beneficial for rapid target selection. Visual Cognition, 7(5), 571-595.

Müller, N. G., Mollenhauer, M., Rösler, A. ve Kleinschmidt, A. (2005). The attentional field has a Mexican hat distribution. Vision Research, 45(9), 1129-1137.

Navon, D. (1977). Forest before trees: The precedence of global features in visual perception. Cognitive Psychology, 9(3), 353-383.

Navon, D. (1981). The forest revisited: More on global precedence. Psychological Research, 43(1), $1-32$.

Niedenthal, P. M. ve Kitayama, S. (Ed.). (2013). The heart's eye: Emotional influences in perception and attention. San Diego: Academic Press.

Pan, F., Wu, X. ve Zhang, L. (2017). Is inhibition of return modulated by involuntary orienting of spatial attention: An ERP study. Frontiers in Psychology, 8, 98-113.

Peirce, J. W. (2007). PsychoPy-psychophysics software in Python. Journal of Neuroscience Methods, 162(1-2), 8-13.

Peters, E., Lipkus, I. ve Diefenbach, M. A. (2006). The functions of affect in health communications and in the construction of health preferences. Journal of Communication, 56, S140-S162.

Posner, M. I. (1980). Orienting of attention. Quarterly Journal of Experimental Psychology, 32(1), 3-25.

Posner, M. I. ve Cohen, Y. (1984). Components of visual orienting. Attention and Performance X: Control of Language Processes, 32, 531-556.

Posner, M. I., Cohen, Y. ve Rafal, R. D. (1982). Neural systems control of spatial orienting. Philosophical Transactions of the Royal Society of London, Series B, Biological Sciences, 298(1089), 187-198.

Posner, M. I., Snyder, C. R. ve Davidson, B. J. (1980). Attention and the detection of signals. Journal of Experimental Psychology: General, 109(2), 160.

Power, M. ve Dalgleish, T. (1997). Cognition and emotion: From order to disorder. New York: Taylor $\&$ Francis Psychology Press.

Remington, R. ve Pierce, L. (1984). Moving attention: Evidence for time-invariant shifts of visual selective attention. Perception \& Psychophysics, 35(4), 393-399.

Russell, J. A. (2003). Core affect and the psychological construction of emotion. Psychological Review, 110, 102-141.

Shulman, G. L., Remington, R. W. ve Mclean, J. P. (1979). Moving attention through visual space. Journal of Experimental Psychology: Human Perception and Performance, 5(3), 500-522.

Srinivasan, N. ve Hanif, A. (2010). Global-happy and local-sad: Perceptual processing affects emotion identification. Cognition and Emotion, 24(6), 1062-1069.

Tekcan, A. İ. ve Göz, İ. (2005). Türkçe kelime normları. İstanbul: Boğaziçi Üniversitesi Yayınları.

Tootell, R. B., Hadjikhani, N., Hall, E. K., Marrett, S., Vanduffel, W., Vaughan, J. T. ve Dale, A. M. (1998). The retinotopy of visual spatial attention. Neuron, 21(6), 1409-1422.

Treisman, A. (1982). Perceptual grouping and attention in visual search for features and for objects. Journal of Experimental Psychology: Human Perception and Performance, 8(2), 180- 194. 
Vuilleumier, P. (2005). How brains beware: neural mechanisms of emotional attention. Trends in Cognitive Sciences, 9(12), 585-594.

Vuilleumier, P. ve Huang, Y. M. (2009). Emotional attention: Uncovering the mechanisms of affective biases in perception. Current Directions in Psychological Science, 18(3), 148-152.

Wadlinger, H. A. ve Isaacowitz, D. M. (2006). Positive mood broadens visual attention to positive stimuli. Motivation and Emotion, 30(1), 87-99.

Walden, T. A. ve Smith, M. C. (1997). Emotion regulation. Motivation and emotion, 21(1), 7-25.

Wegbreit, E., Franconeri, S. ve Beeman, M. (2015). Anxious mood narrows attention in feature space. Cognition and Emotion, 29(4), 668-677.

Wertheimer, M. (1923). A brief introduction to gestalt, identifying key theories and principles. Psychologische Forschung, 4(1), 301-350.

Wolfe, J. M. ve Horowitz, T. S. (2017). Five factors that guide attention in visual search. Nature Human Behaviour, 1(3), 1-8.

Zeelenberg, R., Wagenmakers, E. J. ve Rotteveel, M. (2006). The impact of emotion on perception: Bias or enhanced processing? Psychological Science, 17(4), 287-291. 